NBER WORKING PAPER SERIES

STATES IN FISCAL DISTRESS

Robert P. Inman

Working Paper 16086

http://www.nber.org/papers/w16086

\author{
NATIONAL BUREAU OF ECONOMIC RESEARCH \\ 1050 Massachusetts Avenue \\ Cambridge, MA 02138 \\ June 2010
}

This paper was prepared for the Conference, State and Local Government Amid Economic Turbulence, sponsored by the Federal Reserve Bank of St. Louis and the Weidenbaum Center on the Economy, Government, and Public Policy, Washington University of St. Louis. The comments of my discussant at the conference, Paul Rothstein, are much appreciated. The views expressed herein are those of the author and do not necessarily reflect the views of the National Bureau of Economic Research.

NBER working papers are circulated for discussion and comment purposes. They have not been peerreviewed or been subject to the review by the NBER Board of Directors that accompanies official NBER publications.

(C) 2010 by Robert P. Inman. All rights reserved. Short sections of text, not to exceed two paragraphs, may be quoted without explicit permission provided that full credit, including $\odot$ notice, is given to the source. 
States in Fiscal Distress

Robert P. Inman

NBER Working Paper No. 16086

June 2010

JEL No. H71,H77,H81

\begin{abstract}
The 2007-2010 recession has imposed significant fiscal hardships on state and local governments. The result has been state deficits and the need to increase state taxes, cut spending, and withdraw funds from state rainy day accounts. The primary cause of state budget "gaps" has been the rise in the level of state unemployment. There is no evidence that gaps are related to state political institutions, the state's prior receipt of federal funding, or possibly favored access to key congressional budget committees. The federal government has responded to these gaps with the passage of the American Recovery and Reinvestment Act (ARRA) of 2009 intended to aid states in fiscal distress and to provide an economic stimulus. As insurance for fiscal distress, ARRA covers at most $\$ .23$ of each additional dollar of a state's budget gap; there is a large per capita payment that goes to all states, independent of the level of state deficits. As targeted assistance for stimulating local economies, ARRA funding is uncorrelated with state unemployment rates. ARRA funding appears to be decided by congressional politics, given the desire to pass a major spending and tax relief package as quickly as possible. States are important "agents" for federal macro-policy, but agents with their own needs and objectives.
\end{abstract}

\author{
Robert P. Inman \\ Department of Finance \\ Wharton School \\ University of Pennsylvania \\ Philadelphia, PA 19104-6367 \\ and NBER \\ inman@wharton.upenn.edu
}




\section{STATES IN FISCAL DISTRESS}

by

Robert P. Inman

Richard K. Mellon Professor, Finance, Economics and Public Policy

Wharton School, University of Pennsylvania

Philadelphia, PA 19104

States and their subsidiaries, local governments, have long been the foundation of public finance in the United States, a fact no less true today than at the country's founding. Today state and local governments accounts for over seventy percent of the nation's spending on non-defense public goods and services. As a matter of public policy, we have chosen to decentralize the provision of governmental services, and for good reasons. States and local governments provide significant choice for our mobile residents and businesses for how services get provided and at what levels. Choice encourages states to compete for residents and firms which leads to improved fiscal performance and a better matching of service provision to the wants and needs of families and firms. Having many alternative providers allows successful program innovations to be copied by other states. Finally, with mobile residents, government repression of individual political and civil rights becomes more difficult. For each of these reasons, state governments can play a central role in ensuring a prosperous and democratic society. ${ }^{1}$

States today, however, are under significant fiscal stress. The recent deep economic recession has both reduced state revenues and increased state expenditures, particularly for Medicaid outlays for states’ poverty populations. The end effect has been large state deficits requiring employee layoffs and furloughs, program cuts, and tax increases to restore balanced budgets.

${ }^{1}$ These lessons from U.S. history appear to generalize to other society's and economies as well. See Inman (2007). 
Program cuts have been concentrated in the states two biggest spending categories, state aid to local education and transfers and services for lower income families. In February, 200944 states reported that their anticipated balanced budgets for FY 2009 had turned to deficits. Only those states with significant severance taxes on state natural resources - Montana, Nebraska, North Dakota, Texas, West Virginia, and Wyoming - showed zero expected deficits for the remainder of their fiscal year. These trends have continued into FY 2010. Revenues are still expected to fall below state expenditures, and only through a variety of budget gimmicks such as asset sales, pension underfundings, and dipping into "off-budget” funds will the troubled states be able to balance their state budgets. ${ }^{2}$

It is no surprise then that the states as a group turned to Congress for relief. Congress responded with the passage of the American Recovery and Reinvestment Act (ARRA) in February, 2009. As part of that legislation the federal government provided over $\$ 223$ billion for three years of fiscal relief for state and local governments divided about equally between general fiscal relief for education, Medicaid, and welfare expenditures and program and project specific transfers meant to stimulate the economy.

This paper provides a preliminary evaluation of the ARRA as fiscal relief for states in fiscal distress. It does so against a backdrop of how state finances works best in "normal” times. I reach two conclusions. First, while ARRA did provide significant aggregate fiscal relief to all state governments, the allocation of the program's funds provided at best weak relief for those states in greatest fiscal distress. Only \$.23 of each ARRA dollar was explicitly targeted to closing the states’

2 There is an excellent description of the current state of state finances, and states' budget strategies for dealing with their fiscal crises in National Association of State Budget Officers (NASBO) most recent survey of the states: The Fiscal Survey of States, June, 2009, particularly Tables A-2, A-3, A-5a, and A-5b. The notes to these tables provide the details of how states have chosen to close their fiscal gaps. 
mid-year deficit gaps. The remaining \$.77 of each ARRA dollar went towards increased funding of state services generally or to new programs favored by Congress and the Obama administration. Congressional politics played a significant role in allocating these new programmatic dollars. Second, the analysis of state budgeting in normal times suggests an alternative way to manage state finances in times of fiscal distress. That is to encourage each state to maintain a budget stabilization or "rainy day" fund, perhaps as much as ten percent of general fund expenditures. Pre-FY 2009 levels of such funds were typically less than five percent and in hindsight were insufficient to meet the needs of the current recession. States will only have the incentive to save for such events if Congress can credibly commit to no federal bailouts in times of fiscal distress. Congress first did so in response to the state fiscal crises of the 1840's and has continued this tradition down to President Gerald Ford’s emphatic ‘No’ to the bailout requests of New York City and New York state during their fiscal crises of $1974 .^{3}$

\section{State Budgeting in Normal Times}

State governments perform two essential functions in our public economy. First, states provide state-wide public services not efficiently provided by the state's many local governments. These are services that display significant economies of scale in production or that correct for between community economic externalities, services such as higher education, construction, maintenance, and safety of public highways, prisons and courts, and the protection of water and air quality. Second, states redistribute incomes between residents and provide for minimally acceptable

3 See Inman (2003) and Wallis (2005) for a review of this history and Shefter (1992) for a valuable review of the finance and politics of the New York fiscal crises. 
level of meritorious local services. These redistributive activities include income protection, training, and job placement, the provision of health care services for children and lower income families, and the guarantee through intergovernmental school transfers of a minimally acceptable level of K-12 public education for all children.

Resident, or destination, based taxation will typically be needed to ensure residents pay the full marginal cost of the public services they consume. Resident taxation taxes factors of production by where the factors live, not where they work, and taxes consumption by the location of the consumer. The alternative is source, or origin, based taxation which taxes factors of production by where they work and taxes consumption at the point of purchase. Source-based taxation may allow a share of the tax burden to be shifted onto non-resident owners of productive capital and labor and onto non-resident consumers of goods and services produced within the state. If so, there are two adverse consequences for economic efficiency. First, source-based taxation discourages the efficient location of economic inputs. ${ }^{4} \quad$ Second, because non-residents pay a share of the taxes used to finance the marginal costs of state services, residents or their elected officials may find it advantageous to over-provide the subsidized state services. ${ }^{5}$ For economic efficiency, then, the preferred structure of state taxation is resident-based taxation, ideally resident income, property, and consumption taxation.

Finally, long-term debt can be used to manage large and unexpected expenditures that arise during the fiscal year. Without the ability to borrow to cover such expenditures, states will be forced to raise tax rates significantly. Firms and households typically react to large increases in their tax

\footnotetext{
${ }^{4}$ See Wildasin (1989) and Gordon (1983).

${ }^{5}$ See Inman and Rubinfeld (1996).
} 
rates by a disproportionately large reduction in valued private sector activities such as investment, savings, or work effort. These economic losses, known as the excess burden of the taxation, grow exponentially with the state's tax rate. The use of government debt to pay for such large one-time expenditures allows the government to increase tax rates only slightly and to then hold tax rates stable over the period of debt repayment. This fiscal strategy is called "tax-smoothing” and helps to minimize the efficiency loses of state taxation. ${ }^{6}$ Large state expenditure increases may occur for two reasons: capital outlays for public infrastructure or relief spending to offset loses from natural disasters or deep recessions. Debt financing of state expenditures for either reason is an important component of efficient state financing.

The aim of efficient state government finances is to have each state set their level of public services or transfers so that the marginal benefits of the public dollar just spent equals the marginal costs of financing that dollar. Unfortunately states may not always choose the efficient level of public services or transfers, adopt the efficient tax instruments, or use long-term debt appropriately. In these cases, federal government intervention may be necessary.

First, state spending must allow for all inter-state spillovers. Service spillovers are likely to be most pronounced for states' decisions to redistribute resident incomes or when states provide public goods that directly benefit non-residents. States that engage in higher than average income redistribution will attract lower income residents from other states and drive out upper income residents from their own states. This mobility of residents will discourage states from providing what may otherwise be locally preferred income transfers. The solution to this fiscal externality is federal intergovernmental transfers to states in proportion to the redistributive benefits created for

${ }^{6}$ See Barro (1979). 
residents outside the state or for the added costs borne because of the exit of mobile tax base from within the state. ${ }^{7}$ Federally funded intergovernmental transfers encourage states to provide public goods that offer significant benefits for residents outside the state such as major interstate highways, intercity airports, or infrastructure that protects air and water quality. The preferred form of such transfers will be as a price subsidy or "matching" grant equal to the share of all benefits that are enjoyed by non-residents of the state. ${ }^{8}$

Second, while resident taxation is the efficient way to tax for state services, source-based taxation may be preferred by state residents or their elected officials. Source-based taxation is significantly easier to administer. Taxes on labor income can be collected by a withholding tax administered by firms located within the state. Capital income taxes, once income is apportioned across multiple locations, can also be collected directly from the firms within the state. Finally, sales taxes can be collected at the point of sale rather than requiring residents to keep records of outof-state purchases. In addition to ease of administration, all revenues from source-based taxation collected from non-residents acts as a subsidy to residents for their purchase of state public services. Fortunately, there are federal policies that can solve these administrative problem, while still leaving state residents full control over their choice of tax rates. State resident income and sales taxation can be "piggy-backed" onto the federal income or a federal sales, value-added, or consumption tax. The state selects a tax rate and the federal government collects the revenues from a shared national tax base, say resident income or consumption, as reported by residents of the state. Because of the high mobility of capital and the difficulty of apportioning fixed costs across locations, capital

\footnotetext{
${ }^{7}$ See Wildasin (2000).

${ }^{8}$ See Inman (2002).
} 
taxation is best administered and rates set by the central government. ${ }^{9}$

Third, the federal government may be needed to monitor states’ use of long-term debt. The problem arises when states use long-term debt to finance current year government services. Unless current and future residents, or future factors of production if there is source-based taxation, fully understand the extent of such deficit financing for current services, market and public sector inefficiencies will result. Market inefficiencies occur because future taxes must be increased even though there is no future public asset (in the case of infrastructure) or income insurance program (in the case of disasters) whose benefits compensate for the tax increase. This discourages the location of new private capital or labor in the state, factors whose pre-tax marginal productivity in the state may exceed that in a next best location. Public sector inefficiencies occur because long-term debt used to pay for current services creates a subsidy of those services if that debt is finally repaid by future residents.

There is a market place solution to these deficit-induced inefficiencies, however. If future debt obligations are known to all future residents and firms and if those residents and firms have equally attractive locations in other states - that is, competitive locations are in elastic supply - then any taxes to re-pay long-term debt used to finance prior services must be "rebated" to all new residents and firms before they will locate in the high deficit state. ${ }^{10}$ This can be done for new

${ }^{9}$ See Wildasin (1989), where perhaps some of the proceeds of a national capital tax can be allocated back to states through intergovernmental transfers for support of productive public infrastructure complementary to private capital There is an extensive literature on the design of such tax and transfer schemes; see Krelove (1992) for the theory and Rivlin (1992, Chapter 8) for an application to U.S. federalism.

${ }^{10}$ An assumption of perfect elasticity of new capital to each state is certainly a reasonable assumption for capital. For evidence that residents and productive labor are also elastically supplied to states in the longrun, see Blanchard and Katz (1992). 
residents by either raising resident wages or by lowering the price of land for housing. New firms will enter the state only if there are lower wages or if there is a lower price of land for production. But in the end, it will be the price of land that usually bears the full burden of paying for past deficits. ${ }^{11}$ Land and its valued attributes - mines, oil and gas, fertile farm land, beaches, sunshine, mountains, ports, or historically provided agglomeration economies - is the only factor unique to the state and the one that cannot move to escape the tax. ${ }^{12}$ In the end the debt-induced tax for current services is shifted back onto the owners of state-specific assets in the form of lower rents and entrepreneurial profits. With informed private markets, therefore, those who first received benefits now pay for the benefits.

The problem with the market solution to state deficit financing is in discovering and credibly signaling the level of such debt-financed current accounts deficits. State officials have at least four ways to conceal a deficit. First, at the end of each fiscal year, state officials reveal the deficit but then pass the shortfall into next year's budget with a promise to repay in coming years. If the accumulated debts grows faster than state tax bases, eventually the rollover strategy will collapse and someone will need to cover the aggregated shortfalls. ${ }^{13}$ Second, officials may fail to maintain local capital stocks and not record depreciation of those assets as a current expense. Unlike most

11 See Haughwout and Inman (2001).

12 See Mieskowski (1972) and more recently Rangel (2005). In the “not too” long-run there may also be fixed capital assets in place within the state, the most important of which is the existing housing stock. This fixed capital stock will also be depreciated in price by its share of the costs of long-term debt unmatched by compensating public benefits.

13 This rollover strategy was the central cause of the fiscal crises in New York City (1972), Philadelphia (1990), the German states of Saarland and Bremen (1994), San Paulo (1996), Buenos Aires (1996), and Washington DC (1997). These fiscal histories are described in Rodden, Eskeland, and Litvack (2003). Greece today is a victim of such fiscal mis-behaviors. 
machines, government assets decay gradually, continue to provide services, but then one day collapse. The fall of the Mississippi River bridge connecting the twin cities of Minneapolis and St. Paul killing 13 persons and injuring another 145 is a tragic, but not uncommon, example. Third, states may borrow money for new investments, but then spend those funds on a current service, relabeled perhaps as a “capital outlay.” Finally, states can underfund their workers’ defined benefit pension plans. To ensure there will be sufficient funds to pay workers' promised annuities, state governments must make a contribution that, with accumulated interest, will be sufficient to pay the accumulated annuity from that year's salary. If the government contributes less than the required payment then the pension will be underfunded. Such underfundings are effectively a deficit created to pay part of the compensation of current public employees. ${ }^{14}$ Information about the level of the local debts created by each borrowing strategy is the key to disciplining inefficient deficits.

But who will provide the information? It is unlikely that elected state officials seeking reelection will reveal the true level of state deficits since the deficit strategy gives the appearance of quality services at low tax rates. Future residents and firms might invest in collecting the needed information, but unless all potential buyers of state assets have this information it will be the uninformed buyer who offers the undiscounted price that buys the property. Informed buyers do avoid a potentially bad investment, but the cost of acquiring deficit information must born by each individual buyer and may simply exceed the expected benefits of participating in the market. A "lemons" market may then occur, where high debt states discourage the efficient re-location of

14 See Inman (1982). Inman presents evidence that underfunded public pensions lead to higher worker wages and more public employees than would be observed if worker pensions were fully funded. 
economic activity generally. ${ }^{15}$

Paradoxically perhaps, the only party with an economic interest in providing credible market information are the current owners of assets in the state adopting the deficit strategy. Doing so provides a more liquid market for their private assets and likely higher asset prices when they choose to sell. Importantly, since providing the information is a public good to all buyers, there are significant economies of scale from having the information provided by a single agent - perhaps a supervising agency of the state itself closely monitored by the state's current asset owners. Further, since investing in a state often requires a long-term commitment, having the oversight agency signal a credible commitment to future deficit-free financing is also needed. Let's call these asset owners current homeowners, the agency an elected state supreme court, and the commitment mechanism a constitutionally based balanced budget rule (BBR). Bohn and Inman (1996) find that constitutionally based BBR's enforced by an independently elected state supreme court do in fact provide a significant check on elected state officials’ propensity to run current account deficits. But lacking such a watchdog institution, states may abuse long-term debt financing. ${ }^{16}$

There is one more requirement. For market discipline of state deficits to work, the federal government must not bailout a state when its accumulated deficits threaten state default. If the national government cannot politically resist the temptation to bailout troubled state governments

${ }^{15}$ Of course, the informed buyers could share their deficit information with the uninformed buyers, but why should anyone trust their competitors to tell the truth? The informed buyers have an incentive to announce too high a deficit estimate in hopes of prompting the uninformed buyers to make too low an offer. Since the informed buyer will always lose to the uninformed buyer, there is no incentive to discover the true value. Information here is a public good, shared by everyone but provided by no one.

${ }^{16}$ Inman (1997) provides the formal political economy analysis of self-enforcing balanced budget rules. At the moment, 10 of the 50 states have the institutional structure sufficient for a fully effective BBR. See Bohn and Inman (1996), Table 2, and Hou and Smith (2006). 
because of their macroeconomic or political importance - that is, too big to fail - then political improvidence trumps market discipline. Knowing a bailout is available from the national government, states will shift the cost of state services onto national taxpayers in a beggar-thyneighbor game of deficit financing for current spending. ${ }^{17}$ To qualify as too-big-to-fail, a state default can either impose a large economic cost on the national economy - for example, a financial collapse as Sao Paulo’s default threatened for Brasil in 1996 or as has Greek, Portuguese, or Spanish government debt for the "federal” European Union today - or impose a large loss on a particularly socially favored cohort - as New Orleans' default did following the Katrina hurricane - or threaten a valued social resource not easily duplicated - as was the case for Washington, DC 's default in 1997. Having a federal government with the discipline to say 'no' to a demand for a federal bailout is crucial for efficient state government finances.

Against these benchmarks for fiscal efficiency then, how do U.S. states do in normal times? For the sector as a whole, aggregate fiscal performance seems fine. States largely spend money on residential services and federal intergovernmental assistance is being used when across state spillovers occur. State taxes are largely residential. And most states have balanced budgets with small annual contributions to a "budget stabilization fund" for unforeseen shocks to the state's economy.

For example in fiscal year (FY) 2006, the last pre-recession year, state spending for current services and transfers was $\$ 4,430$ per person, divided as $\$ 1,725$ for state services such as highway maintenance, courts and prisons, and protection of natural resources and $\$ 2,705$ for general transfers

17 This beggar-thy-neighbor fiscal game is described in Inman (2003) and then applied by others in country case studies in Rodden, Eskeland, and Litvack (2003). 
including welfare and Medicaid and school aid. State spending for new infrastructure was about \$340 per person. States paid for these services and transfers largely through residential taxes: 25 percent from residential income taxes, 24 percent from general sales taxation, and 32 percent from resident user fees and "sin” taxes. Together these residential taxes and user fees totaled 7.2 percent of personal income. The remaining share of state revenues were collected from businesses through business fees and a state corporate income tax. The state corporate income tax is the only significant source-based tax and it contributed only 5 percent to aggregate state revenues in 2006. Most all capital spending by states is paid for through the issuance of long-term debt. ${ }^{18}$

Each year there is a significant gap between the states’ own revenues from fees and taxes and the states’ spending for current spending. Again for FY 2006, states’ own revenues covered \$3,236 per person of the states’ $\$ 4,430$ per person in current spending. The resulting gap of $\$ 1,194$ per person was more than covered by $\$ 1,290$ per person in intergovernmental transfers from the federal government. Those grants paid for income transfers, Medicaid, and related services for state residents in poverty (\$750/person), for interstate highway construction and maintenance within the state (\$110/person), and for a miscellaneous collection of targeted small programs of value to state residents (\$430/person). ${ }^{19}$ Together, the states’ own revenues plus federal aid equaled $\$ 4,526$ per person, a bit more than enough to cover current spending. In 2006, the average state was able to run a current accounts fiscal surplus equal to own revenues plus federal aid $(\$ 4,526)$ minus current

18 Source: Statistical Abstract of the United States, 2010, Table 439. These figures and those for federal aid below are from the Census of Government, 2006, and include all state spending and revenues.

${ }^{19}$ Inman (1988) provides an evaluation of these many programs against the standards of good public finance. Not surprisingly, federal politics are an important determinant of the final allocation of federal dollars. We will find a similar conclusion in our evaluation of the recent federal programs designed to help states' during the current fiscal crisis; see Section IV below. 
spending $(\$ 4,403)$ of $\$ 96 /$ person or about 2 percent of current spending. In the aggregate, state deficit financing has been under control. These states’ surpluses have been saved in "rainy day” or fiscal stabilization funds for future fiscal emergencies. By the end of FY 2006, states in the aggregate had accumulated over $\$ 30$ billion in savings for future fiscal contingencies. ${ }^{20}$

Against the guidelines for efficient state budgeting, there is much to recommend this aggregate fiscal performance by U.S. states. In FY 2006, states were spending money on appropriate state functions, raising most of their money with efficient resident-based taxes, and running small fiscal surpluses on the current accounts. For the most part, the federal government provides assistance for those state services where there are arguably significant inter-state spillovers and does so with appropriate price-based subsidies. By most measures, states were fulfilling their assigned role in our federal system of public finance in FY 2006.

But those were normal times. Today state governments are in deep fiscal distress. The question now arises: Should the guidelines for good state financing be relaxed when states' face the threat of deep service cuts or large tax increases? If so, how does the state assistance provided by the American Recovery and Reinvestment Act fit into such revised guidelines?

\section{Understanding Today's Fiscal Crisis}

In January 2006, the national unemployment rate was 4.7 percent. By February, 2009, the rate had more doubled to 9.5 percent and the U.S. economy was in the midst of its deepest recession since the 1930 's. The impact of the recession on state budgets has been significant. By the middle of the FY 2009, forty-four states were facing significant fiscal deficits totaling over $\$ 78$ billion or

\footnotetext{
20 See Table 1 below.
} 
about \$260/person. Mid-year deficits as a share of budgeted spending for FY 2009 equaled 12 percent. Only those states with significant “severance” taxes on their state’s production of oil, gas, and coal were immune to the deficit pressures. Since most states are precluded by their constitutions from making changes to tax rates during the fiscal year, these looming deficits meant significant cuts in state services. These fiscal pressures have continued into FY 2010. Was the recession alone to blame, or where there inherent weaknesses within the fiscal structure of state financing that only a deep recession could expose? Knowing the answer to this question will help us evaluate the policy responses of states, and ultimately, the national government to this crisis.

Table 1 summarizes the aggregate fiscal performance of the general fund for state governments since FY 2006. ${ }^{21}$ In FY 2006, states’ general funds were comfortably in balance. All states' revenues - including aid from the federal government - exceeded states' spending by the positive state balance $\$ 18.2$ billion; Table 1, col. [3]. This balance can be allocated to a variety of uses in the states' "capital accounts” such as paying down long-term debt, investing in capital improvements, or adding to the states' stabilization ("rainy day") funds. Some states adopted a variation of the savings strategy by “rolling-over” the surplus from FY 2006 into the new budget being planned for FY 2007..$^{22}$ The aggregate fiscal position of all state governments at the end of FY 2006 is the sum of their surpluses at the end of that year, \$18.2 billion, plus the accumulated savings from prior years now in their stablization funds, $\$ 22.4$ billion (Table 1, col. [4]). The total fiscal balance for states’ in FY 2006 was $\$ 40.6$ billion or \$136/person (Table 1, col. [5]).

${ }^{21}$ It should be noted that the levels of funding reported in Table 1 are limited to the states' general fund while the level of funding reported in Section II for FY 2006 includes all current accounts spending.

22 This is simply an accounting step. Rolled-over surplus is placed in an interest-bearing account until it is spent in the next fiscal year just as the state would do if the funds were placed in a separate stablization fund. The possible virtue of an explicit stablization fund is its transparency to citizens. 
The recession officially began in December, 2007 but states did not begin to feel its full impact on overall fiscal balances until FY2008. FY 2007 ended with budgets effectively in balance. There was a small aggregate deficit of $\$ 1.9$ billion (Table 1 , col. [3]) that was more than covered by accumulated prior surpluses of $\$ 29.1$ billion in the states’ stablization funds (Table 1, col. [4]). By the end of FY 2008, however, the national rate of unemployment had risen to 5.5 percent, the $S$ and P 500 index had fallen from its peak of 1549 in October 2007 to 1280 by June, 2008. States were beginning to feel significant pressure on their budgets. State revenues feel slightly from FY 2007 (- $\$ 2$ billion), but state spending rose by $\$ 11.5$ billion, particularly state spending for redistributive services. The net effect was to increase annual state deficits by $\$ 13.5$ billion from $\$-1.9$ billion in FY 2007 to a more significant $-\$ 15.4$ billion at the end of FY 2008; Table 1, col. [3]. Fortunately, states' stablization funds of $\$ 35$ billion were still sufficient to cover this gap and the overall fiscal balance for all states was $\$ 19.6$ billion; Table 1, col. [5].

Not so by the end of FY 2009. States' had begun to make significant adjustments in state spending in anticipation of continued falling revenues, but those adjustments were not enough to prevent an almost doubling of the deficit of the states' general funds. From FY 2008 to the end of FY 2009, aggregate state revenues fell by $\$ 30.9$ billion (Table 1, col. [1]), but state spending was reduced by only $\$ 14.7$ billion (Table 1, col. [2]). The net effect was to increase the states' aggregate deficits from -\$15.4 billion at the end of FY 2008 to $-\$ 31.6$ billion at the end of FY 2009 (Table 1, col. [3]). This total deficit fully exhausted all of the $\$ 30.4$ billion of accumulated savings in the states’ stablization funds (Table 1, col. [4]) leaving an aggregate deficit for the state sector of $-\$ 1.2$ 
billion. ${ }^{23}$ Going forward into FY 2010, states are planning for continued cuts to state spending and

for increases in state revenues. Still these adjustments will leave a planned general fund deficit of \$5.7 billion for this fiscal year for all states. ${ }^{24}$

Table 2 seeks to find the likely correlates in the states’ economies, the states’ budgeting, or the states’ politics that might suggest the likely explanation for the large FY 2009 mid-year deficits. The dependent variable is the reported mid-year anticipated deficit in state budgets as of February,

${ }^{23}$ This aggregate total conceals a deeper and wider problem, however. In the aggregates are the states with zero or small deficits in FY 2009, in particular, the resource rich states of Alaska, Montana, Nebraska North Dakota, Texas, West Virginia and Wyoming . If we compute Table 1, col. [5] for all states excluding Alaska and Texas, then at the end of FY 2009, the other 48 states had a deficit in their general funds of $-\$ 30.6$ billion and accumulated savings in their stabilization funds of only $\$ 16.9$ billion. Thus the remaining 48 states had an overall fiscal balance of - $\$ 13.7$ billion or about $\$ 50 /$ person.

It is reasonable to ask: How were these states able to cover the remaining $\$ 13.7$ billion in state spending? The answer has been to sell state assets, move monies from state funds such as the Tobacco Settlement Fund that had been earmarked for future spending, and to play the game of allocating May and June tax revenues committed to FY 2010 into paying for FY 2009 spending. It is interesting to note that the planned level of the states' stabilization funds at the end of FY 2010 are still significantly positive at \$28.8 billion, even though FY 2010 shows an anticipated general funds deficit of $-\$ 5.7$ billion. How can that be? The answer is that states did not fully exhaust their available FY 2009 stabilization funds to cover their FY 2009 deficits. In fact that used only $\$ 1.6$ billion for that purpose (= FY2009 Fund - FY2010 Fund $=\$ 30.4 \mathrm{~B}$ \$28.8B; Table 1, col. [7]). This means that most of the FY 2009 deficit had to be covered by budget reallocations from other funds not included in general fund accounting. How this could be done is detailed in National Association of State Budget Officers, Fiscal Survey of States, June, 2009, Notes to Table A-2.

Finally, California is always worthy of a special look. Its FY 2009 general fund deficit was $-\$ 4.7$ billion. The state had accumulated $\$ 2.3$ billion in prior general fund savings - California uses the roll-over approach to account for state savings - for net end of FY 2009 position of \$-2.4 billion. This is a net fiscal position of -\$66/person. Source: National Association of State Budget Officers, Fiscal Survey of States, June, 2009, Table A-2. Interesting too is the fact that California is the one state with significant deficits that did not detail how they planned to fill their revenue gap from non-general fund sources; there is no California entry to the Notes to Table A-2 for FY 2009.

${ }^{24}$ It is very interesting to note that the states anticipate having an aggregate level of state stablization funds of $\$ 28.8$ billion! From where? The previous year shows an overall balance of $-\$ 1.2$ billion so it cannot be from prior savings. And they are estimating revenues will be less than spending for FY 2010. There must be an "outside source" of new money that the states' anticipate that is not included in their usual revenue projections. Could it be from one time federal assistance through the American Recovery and Reinvestment Act of 2009? That Act plans to allocate \$110 to \$150 billion to states over the fiscal years 2009 and 2010. It would appear that states are planning to allocate approximately $\$ 28.8$ billion of those funds to replenishing their rainy day funds suggesting that about $\$ .20$ to $\$ .25$ of every ARRA dollar will be saved for a latter fiscal crisis. 
2009, called the states' budget gaps. This measure removes all mid-year adjustments to spending and revenues that the states' were able to make before the end of FY 2009 and therefore provides an estimate of the "structural" gap created by the fiscal shock of the recession. ${ }^{25}$

Table 2, col. [1] reports the partial correlations of attributes of the states' economies with the size of their mid-year budget gap. ${ }^{26}$ The most important correlate with a state's budget gap is the state's unemployment rate as of February, 2009. The mean unemployment rate is 8.0 percent with a standard deviation of 2 percent within the sample. States with a one standard deviation higher rate of unemployment (10.0\%) will have a budget gap which is $\$ 222 /$ person more than a comparable state with an unemployment rate one standard deviation lower than average (6\%): \$220/person = $\Delta \mathrm{UE} \bullet 55.61=4.0 \bullet 55.61=\$ 222.41 /$ person. States with larger populations also have a larger per capita deficit gaps. Interestingly, it is not the larger manufacturing states that have the biggest budget gaps; the percent of state workers in manufacturing had a negative effect on states' anticipated deficits.

Table 2, cols. [2]-[4] adds state fiscal variables to the analysis to explore the possible impact of the structure of state budgeting on the FY 2009 budget gap. All fiscal variables are from FY 2005, though measured in FY 2009 dollars. The aggregate size of the state budget in FY 2005 is important, but the share of the FY 2005 budget that is allocated to the major redistribution program - Medicaid - has no significant effect on the budget gap; see Table 2, col. [2]. There is no evidence

25 The mid-year adjustments were significant. The reported budget gaps as of February, 2009 averaged \$257/person or $-\$ 78.6$ billion. By the end of FY 2009, the final deficits in Table 1 are $-\$ 31.6$ billion; see Table 1, col. [5]. States were able to trim their mid-year anticipated deficits by more than half.

${ }^{26}$ Since the results here are for a one-year cross-section regression of all 50 states one needs to be cautious about using the word "causal." I repeated the analysis in Table 2 omitting California and then Alaska and Texas and the results are nearly the same. 
that state expectations of "outside” funding encouraged a larger budget gap in FY 2009. Neither federal aid in FY 2005, nor large holdings of cash and securities in a rainy day fund in FY 2005, nor having a Senate budgetary chairman from your state are correlated with the "surprise" deficits of FY 2009; see Table 2, col. [3].

Table 2, col. [4] tests for the presence of "California behavior.” Over the past ten years California budgets have relied heavily on capital gains taxation for the financing of state services and have increased state spending with increases in these tax revenues. Unfortunately, when revenues decline, the state legislature has been unable to agree on comparable cuts in state spending. The result has been large state deficits during economic downturns. ${ }^{27}$ Perhaps the use of high variance taxes and the adoption of high variance spending programs leads, as it has in California, to larger budget gaps. I test this proposition by adding the coefficient of variation of state revenues and spending for the twenty years prior to FY 2005 to the core regression. Fortunately California's budget behavior does not appear to be a general phenomenon; measures of state revenue and spending volatility are uncorrelated with the current FY 2009 budget gaps across all states.

Table 2, col. [5] examines whether state political institutions are correlated with the size of the 2009 budget gap. There is no evidence here that larger state legislative bodies or Democratic governors correlate with larger state budget gaps in FY 2009. The political economy literature has found larger state legislatures do spend more, but at least for FY 2009 it appears they also committed to higher taxes. ${ }^{28}$ Democratic governors may also spend more, but again in FY 2009, they seemed

\footnotetext{
27 Sheffrin (2004) provides a detailed and compelling analysis of California’s budget "debacle”his word, not mine - from this perspective. Matsusaka (1995).

28 On the positive effects of the size of state legislatures on state spending, see Gilligan and
} 
to have taxed more too.

In the end, the most important correlate with the February 2009 budget gap is the national recession, coupled with hopeful forecasting by the states as to future state revenues and redistributive spending. The national unemployment on June 30, 2008 was 5.5 percent. One year later at the end of FY 2009, the unemployment rate was 9.5 percent. If budgets had been based on the 2008 unemployment rate, then this 4 percent increase would imply a $\$ 180 /$ person $(=4.0 \times 44.81$, Table 2, col. [6]) to a $\$ 222 /$ person (= $4.0 \times 55.61$, Table 2, col. [1]) budget gap, accounting for almost all of the variation in observed mid-year deficits seen in the data. The good news from this analysis is that the states' fiscal crises of 2009 do not appear to be linked to any obvious structural or institutional failures in state finances. It's the economy.

\section{The Federal Response}

Much as states are meant to facilitate efficient resource allocations between local governments in a well designed federal system of public finance, so too is the national government meant to intervene when there are economic spillovers or allocative failures between the states. The current recession is arguably such a moment. The recession has threatened the ability of states to provide core services, particularly redistributive services, to their constituents. Further, as small open economies in a large economic union, state governments may be very limited in their ability to use economic stimulus strategies to restore the states's employment and growth to their prerecession levels. Free trade and factor mobility between states mean any state’s fiscal stimulus will be shared by citizens nationally, at least in the long-run. ${ }^{29}$ Both for reasons of fiscal insurance for

${ }^{29}$ Gramlich (1987) estimates that at most \$.10 of every dollar of increased state fiscal stimulus, say in the form of increased state deficit spending, remains within the state to stimulate the states economy. Even 
core state services and to stimulate the national economy, federal government intervention may be appropriate.

Congress responded with the passage of the American Recovery and Reinvestment Act (ARRA) on February 17, 2009. The stated purposes of the legislation are to stimulate the national economy through $\$ 288$ billion in tax cuts and $\$ 499$ billion in new spending and to protect state and local public services by sending $\$ 223$ billion of the new spending to the states for support of core state services. The $\$ 223$ billion in ARRA assistance to the states is to be disbursed over the three fiscal years beginning in FY 2009 and ending in FY 2011, thought to be sufficient time for the states’ economies to recover from the recession. The total three-year allocation of $\$ 761 /$ person equals three years of the mid-year FY 2009 budget gap of \$257/person. In the aggregate, ARRA funding appears to be sufficient to protect the level of spending states' had planned in the spring of 2008 for their FY 2009 budgets, before the full force of the economic decline was evident. As fiscal insurance, therefore, the overall level of federal funding is sufficient to close state budget gaps. Table 3 shows how the $\$ 223$ billion of state assistance is to be allocated across states.

How well does ARRA state funding do in meeting its twin objectives of protecting core state services and responding to states in economic distress? The performance is mixed. If the objective of ARRA funding is to fully protect state services in each distressed state, then we should expect a simple regression of total ARRA assistance against the budget gap to have an intercept close to zero and a slope near 1.0 - that is, be a $45^{\circ}$ line. In fact, the intercept is $\$ 695$ per person and is statistically significant and the slope is only .25 and statistically different from both zero and 1.0; see Table 3, col. [1]. There is fiscal insurance, but it is not full coverage for the state's at risk, even

if the state economy does improve, Blanchard and Katz (1992) provide evidence that workers from other states will eventually move into the growing state and erode the economic gains for current residents. 
for the marginal dollar of fiscal distress. ${ }^{30}$

If ARRA assistance is meant to be a combination of targeted fiscal insurance and an economic stimulus for the declining states, then we should expect significant positive coefficients on the levels of both state budget gaps and state unemployment rates in a total ARRA funding equation; see Table 3, col. [2]. We continue to observe partial insurance coverage but no observable effort to match ARRA funding to state unemployment rates. Partitioning state ARRA funding into its four main spending categories - stability aid meant to protect state jobs (Table 3, col. [3]), Medicaid aid as a supplement to usual federal Medicaid funding (Table 3, col. [4]), highway aid meant for "shovel ready" construction projects (Table 3, col. [5]), and a collection of old and new programs in “other aid” (Table 3, col. [6]) - and regressing individual category aid on the state unemployment rate, state budget gap, and category specific determinants still reveals no effort to match ARRA funding to high unemployment states and only modest success at closing state budget gaps. If not full fiscal insurance or a targeted economic stimulus, what then is ARRA funding to states seeking to do?

The evidence in Table 3 suggests two goals. First, stimulate the national economy using states’ as agents for spending federal money. Second, pass an aggregate economic stimulus package as quickly as possible.

${ }^{30}$ This result is from a comparison of an annual (FY 2009) budget gap with a proposed three years of total fiscal assistance. It is preferable to have the budget gap and the proposed aid cover the same fiscal period. Unfortunately we do not know what the future budget gaps will be, nor do we know the exact time path of payments of aid. As an alternative approach, I re-specified the budget gap variable to be for three years. This reduced the estimated coefficient for the budget gap variable by $1 / 3$ in all columns of Table 3 , as expected. Thus the marginal insurance effect on an annualized basis is even smaller than estimated here. Alternatively, I reduced the total level of fiscal assistance by $1 / 3$ to represent an approximation to an annual flow of federal aid. This too reduced coefficient on the budget gap variable by $1 / 3$ and the intercept by $1 / 3$ as well. All other coefficients are unchanged. The results in Table 3 most likely provide an upper estimate of ARRA’s marginal insurance effect. 
To get money into the national economy, the federal government must use existing government agencies and government programs. States are effectively federal "agencies" for the purpose of spending federal money, and education aid to states, Medicaid funding, and highway construction grants are three prominent federal programs. Education aid is the most important component of ARRA assistance called "stability aid.” Together these three spending categories stability, Medicaid, and highway aid - account for just over two-thirds of all state ARRA funding.

To assure quick passage of a stimulus program a credible political strategy might be to: (i) give all states some funding; (ii) not open new, or revisit old, distributional conflicts between the states, and finally, (iii) give a bit extra to the states represented by the chairs and senior members of the important budgetary committees. In fact, passage of ARRA took less than one month from its introduction as H.R. 1 on January 26, 2009. The House approved the final bill by a vote of 246183 (No Republican support) and the Senate voted 60-38 (3 Republican Yea votes).

How were ARRA funds allocated? First, everyone got some aid. The results in Table 3 reveal that stability aid works as a simple per capita grant, worth on average $\$ 160$ per person (plus or minus a little bit); see Table 3, col. [3]. Second, ARRA used existing federal programs and their distribution formulas to avoid opening up an unstable redistribution game between all legislators. ARRA selected one program that favored liberal, large, and high poverty urban states - Medicaid aid; see Table 3, col. [4] - and a second that favored conservative, small, rural states - highway aid, see Table 3, col. [5]. Finally, select many small programs, and create some new ones, that can be targeted as "Other Aid" to specific members as their interests require, paying particularly close attention to the states with Senators who run the major budget committees; see Table 3, col. [6]. ${ }^{31}$

31 That congressional politics is an important determinant of ARRA spending should come as no surprise. This has been the "truth" of federal aid to state and local governments since the 1950's; see Inman 
Finally, there no evidence that presidential politics was decisive in the allocation of ARRA funding. In particular, states that provided Obama with his presidential election margin - Florida, Georgia, Indiana, North Carolina, and Ohio - did not receive additional ARRA support.

Viewing total ARRA funding as a single federal policy, it is best described as a three year formula grant providing temporary fiscal relief from rising medicaid costs and short-term fiscal stress with a few dollars for highway construction and a lot of lump-sum aid per capita in the guise of expanded and new program initiatives; Table 3, col. [7]. The average state will receive \$290/person for medicaid support $(=.392 \bullet$ Ave. Medicaid Exp, '05 = .392•\$741/person) plus $\$ 60 /$ person for relief for fiscal distress $(=.232 \bullet$ Ave. Budget Gap '09 = .232•\$257/person) plus \$49/person for highway construction (= 3.95•Ave. Highway Miles = 3.95•12.33 miles/person) plus \$415/person as a per capita grant. Together these four components equal \$814/person, accounting for all the funding to be allocated by ARRA.

(1985). Here, the importance of "Other Aid" to the passage of ARRA is evident from a simple regression of states' Senators support measured as 1 (if both Senators supported the bill), 0 (if Senator support is split), and -1 (if both Senators opposed the bill) on three variables: Obama (=1, if President Obama won the state's popular vote, 0 otherwise), Pop (= state population), and OthAid (= Other Aid per person allocated to the state).

$$
\text { Senate Support }=-1.22+1.15 \bullet \text { Obama }-.00001 \bullet \text { Pop }+.004 \cdot \text { OthAid } \quad \mathrm{R}^{2}(\text { Adj })=.48
$$

$$
\begin{array}{lll}
(.44) \quad(.17) \quad(.00001) \quad(.002)
\end{array}
$$

All regression coefficients except that on Pop are significant at the 5 percent level or smaller. To interpret the results notice that a non-Obama state $($ Obama $=0)$ receiving no OthAid would be unambiguously opposed to the legislation - that is, Senate Support would equal -1. An Obama state receiving no OthAid would divide its Senators' votes - that is, Senate Support would equal 0. Allocating OthAid at its mean level of \$240/person will be sufficient, however, to turn an original non-Obama state from a no Senate support to a split Senate vote, and an Obama state from a split vote state into one with full support for ARRA: $.004 \bullet$ OthAid $=.004 \cdot 240=.96$. Finally, as a test that it was Other Aid that helped to determine Senate Support for ARRA, I ran the same regression as above but replaced Other Aid with the state's allocation of Stability Aid, then Medicaid Aid, and then Highway Aid. None of the other aid categories had a significant effect on Senate Support for ARRA. 


\section{Conclusion}

Today’s deep recession has imposed significant fiscal hardships on our state governments. States have adjusted, but not without cuts in government spending and significant federal assistance through ARRA. As fiscal insurance for troubled state budgets, ARRA aid is relatively inefficient. The program provides a large per capita grant to all states, troubled or not, while closing at best \$.23 of each individual state's recession induced budget shortfall. ARRA's large component of per capita assistance is understandable perhaps, since ARRA had a second objective of stimulating as quickly as possible the aggregate economy with an large infusion of federal monies. To achieve the stimulus objective it was necessary to use existing federal programs, and many of the largest (non-defense) federal programs - school aid, personal transfers, and construction - are administered by state governments. To ensure ARRA would pass quickly, congressional politics seems to have required that all states get significant funding. We have muddled through, but alternatives should be considered.

What is often needed in times of deep recessions is protection for state budgets and a quick fiscal stimulus for the macro economy. One alternative is a permanent federal program of fiscal insurance for state budgets, triggered either by a high level of an individual state’s, or the Nation’s, rate of unemployment. Such a program is likely to create adverse incentives for at least four important state decisions, however. First, just as households have reduced precautionary savings in response to federal income insurance (welfare and medicaid) so too might we expect states to reduce their contributions to their states' rainy day funds. Second, with such insurance states may prefer high variance tax instruments. Germany has a variant of fiscal insurance for lower-tier governments and there is strong evidence that these governments have moved their tax structures 
towards more volatile business taxes and away from more stable residential taxes. ${ }^{32}$ Third, states may lock in spending programs, either formally by contracts or informally by political agreements, that were economically attractive when private incomes were high but are no longer economically justified when private incomes are low. Finally, if tied to state unemployment rates, such fiscal insurance would act as a deterrent to the efficient location of economic activity. Workers and capital may be discouraged from moving out of declining industries in declining states, and states may be encouraged to more aggressively pursue the location of cyclically sensitive industries.

Rather than federal fiscal insurance, a second alternative is to strengthen the institutions for state finances in "normal times." This approach begins by re-confirming the federal government's commitment to not bail-out state governments in times of deep recessions. The no bail-out pledge places the burden of insuring against bad economic shocks in the hands of the states' citizens. Citizens can then save individually to smooth out bad fiscal shocks to state and local taxes and services. Or they can self-insure collectively as they now do through state government's budget stabilization funds, though perhaps funded at a greater percentage of general fund expenditures than the current norm of five percent. ${ }^{33}$

Finally, and under either insurance strategy, an aggregate fiscal stimulus may still be needed in deep recessions to encourage a return to national economic growth and full employment. The best available evidence suggests that direct federal tax and transfer policies rather than intergovernmental aid to states are likely to be the more effective policies for this objective. ${ }^{34}$ State governments are

32 See Buettner (2007).

33 See Sobel and Holcombe (1996) and Joyce (2001).

${ }^{34}$ See Blanchard and Perotti (2002), Johnson, Parker, and Souleles, (2006), and Romer and Romer (2010). 
valuable partners in our system of fiscal policy-making, but their central function, and the one to which their current fiscal institutions seem best suited, is to provide public services to residents at competitive tax rates. 


\section{TABLE 1: STATE UNDER FISCAL STRESS*}

\begin{tabular}{|c|c|c|c|c|c|}
\hline $\begin{array}{c}\text { FISCAL } \\
\text { YEAR }\end{array}$ & $\begin{array}{c}\text { General Fund State } \\
\text { Revenues } \\
{[1]}\end{array}$ & $\begin{array}{c}\text { General Fund State } \\
\text { Expenditures } \\
{[2]}\end{array}$ & $\begin{array}{c}\text { General Fund State } \\
\text { Balances* } \\
\text { [3] }\end{array}$ & $\begin{array}{c}\text { General Fund State } \\
\text { Stabilization Fund } \\
{[4]}\end{array}$ & $\begin{array}{c}\text { Overall Fiscal } \\
\text { Balance } \\
\text { [5] }\end{array}$ \\
\hline 2006 & \$622.0B & \$603.8B & $\$ 18.2 \mathrm{~B}$ & $\$ 22.4 \mathrm{~B}$ & $\$ 40.6 \mathrm{~B}$ \\
\hline 2007 & \$671.3B & $\$ 673.2 B$ & $-\$ 1.9 B$ & \$29.1B & $\$ 27.2 \mathrm{~B}$ \\
\hline 2008 & \$669.3B & \$684.7B & $-\$ 15.4 \mathrm{~B}$ & $\$ 35.0 \mathrm{~B}$ & \$19.6B \\
\hline 2009 & \$638.4B & $\$ 670.0 \mathrm{~B}$ & $-\$ 31.6 B$ & $\$ 30.4 \mathrm{~B}$ & $-\$ 1.2 \mathrm{~B}$ \\
\hline $2010^{\dagger}$ & $\$ 647.2 B$ & $\$ 652.9 B$ & $-\$ 5.7 B$ & $\$ 28.8 B$ & $\$ 23.1 \mathrm{~B}$ \\
\hline
\end{tabular}

Source: National Association of State Budget Officers, Fiscal Survey of States, June (2007, 2008, 2009), Tables A-1, A-2, and A-3. All figures are in 2009 dollars.

* Fiscal information is the for states' General Funds. The state balances reported here are the differences between state revenues in column [1] minus state expenditures reported in column [2]. This measure of balance differs from the "ending balance" reported in the Fiscal Survey as it excludes all revenue "adjustments" and expenditure "adjustments." Such adjustments typically include the reallocation of revenues and spending obligations from a variety of "off-budget" funds - for example, revenues from the Tobacco Settlement Fund, revenues from pension obligation bonds, interest payments from bond sinking funds, and transfers into the current budget from the state's Rainy Day Fund. See notes to Tables A-1, A-2, and A-3, Fiscal Survey of States, June $(2007,2008,2009)$. Finally, California, Colorado, Delaware, Georgia, Massachusetts, Minnesota, New Jersey, New Mexico, New York, and South Carolina report their state's stabilization fund as part of each fiscal year's ending balance. Therefore, to provide an overview of all states' final fiscal balance at the end of each fiscal year, I combine columns [3] and [4] and report the results in column [5].

† The results for FY 2010 are projected numbers as of June, 2009. 
TABLE 2: DETERMINANTS OF STATES’ 2009 BUDGET GAPS ${ }^{\dagger}$

\begin{tabular}{|c|c|c|c|c|c|c|}
\hline $\begin{array}{c}\text { Average Budget Gap = } \\
\$ 257 \\
(\text { S.D. }=233)\end{array}$ & $\begin{array}{l}\text { Budget } \\
\text { Gap } \\
(1)\end{array}$ & $\begin{array}{l}\text { Budget } \\
\text { Gap } \\
\text { (2) }\end{array}$ & $\begin{array}{l}\text { Budget } \\
\text { Gap } \\
\text { (3) }\end{array}$ & $\begin{array}{l}\text { Budget } \\
\text { Gap } \\
\text { (4) }\end{array}$ & $\begin{array}{l}\text { Budget } \\
\text { Gap } \\
\text { (5) }\end{array}$ & $\begin{array}{l}\text { Budget } \\
\text { Gap } \\
\text { (6) }\end{array}$ \\
\hline Constant & $\begin{array}{l}3.03 \\
(113)\end{array}$ & $\begin{array}{l}-131.2 \\
(155.8)\end{array}$ & $\begin{array}{c}190.9 \\
(179.5)\end{array}$ & $\begin{array}{r}-290.02 \\
(202.3)\end{array}$ & $\begin{array}{l}-29.06 \\
(214.9)\end{array}$ & $\begin{array}{l}-183.5 \\
(131.8)\end{array}$ \\
\hline $\begin{array}{c}\text { State UE } \\
\text { February, '09 } \\
\text { (S.D. }=2.03 \text { ) }\end{array}$ & $\begin{array}{c}55.61 \\
(14.60)^{*}\end{array}$ & $\begin{array}{c}45.09 \\
(14.67)^{*}\end{array}$ & $\begin{array}{c}38.68 \\
(18.18)^{*}\end{array}$ & $\begin{array}{l}48.70 \\
(15.50)^{*}\end{array}$ & $\begin{array}{c}41.51 \\
(15.66)^{*}\end{array}$ & $\begin{array}{c}44.81 \\
(14.56)^{*}\end{array}$ \\
\hline $\begin{array}{c}\text { State } \\
\text { Population } \\
\text { (S.D. }=6,672)\end{array}$ & $\begin{array}{l}.005 \\
(.004)\end{array}$ & $\begin{array}{l}.010 \\
(.004)^{* *}\end{array}$ & $\begin{array}{l}.008 \\
(.005)\end{array}$ & $\begin{array}{l}.010 \\
(.005)^{*}\end{array}$ & $\begin{array}{l}.010 \\
(.005)^{*}\end{array}$ & $\begin{array}{c}.010 \\
(.004)^{*}\end{array}$ \\
\hline $\begin{array}{c}\text { Percent } \\
\text { Manufacturing } \\
\text { (S.D. = .065) }\end{array}$ & $\begin{array}{l}-1599 \\
(422.7)^{*}\end{array}$ & $\begin{array}{l}-883.3 \\
(500.7)^{*}\end{array}$ & $\begin{array}{l}-1353.4 \\
(532.4)^{*}\end{array}$ & $\begin{array}{l}-1126.1 \\
(504.8)^{*}\end{array}$ & $\begin{array}{l}-901.3 \\
(496.3)^{*}\end{array}$ & $\begin{array}{l}-977.1 \\
(475.5)^{*}\end{array}$ \\
\hline $\begin{array}{l}\text { State Budget, } \\
\text { '05 } \\
\text { (S.D. = } \$ 1,685 \text { ) }\end{array}$ & - & $\begin{array}{l}.045 \\
(.019)^{*}\end{array}$ & - & $\begin{array}{c}.092 \\
(.044)^{*}\end{array}$ & $\begin{array}{c}.039 \\
(.029)\end{array}$ & $\begin{array}{l}.046 \\
(.019)^{*}\end{array}$ \\
\hline $\begin{array}{l}\text { Share of Budget } \\
\text { Medicaid, '05 }\end{array}$ & - & $\begin{array}{l}-294.0 \\
(459.9)\end{array}$ & - & - & - & - \\
\hline $\begin{array}{l}\text { Federal Aid } \\
\quad 05\end{array}$ & - & - & $\begin{array}{l}-.076 \\
(.095)\end{array}$ & - & - & - \\
\hline $\begin{array}{c}\text { Cash/Securities } \\
\text { '05 }\end{array}$ & - & - & $\begin{array}{c}11.30 \\
(22.06)\end{array}$ & - & - & - \\
\hline $\begin{array}{c}\text { Senate } \\
\text { Chairman }\end{array}$ & - & - & $\begin{array}{l}-56.51 \\
(75.81)\end{array}$ & - & - & - \\
\hline $\begin{array}{l}\text { Coef. of Variation } \\
\text { State Revenues, '05 }\end{array}$ & - & - & - & $\begin{array}{l}-387.4 \\
(1910)\end{array}$ & - & - \\
\hline $\begin{array}{l}\text { Coef. of Variation } \\
\text { State Expenditures, '05 }\end{array}$ & - & - & - & $\begin{array}{c}213.1 \\
(2067)\end{array}$ & - & - \\
\hline State Senate Seats & - & - & - & - & $\begin{array}{l}-1.53 \\
(2.73)\end{array}$ & - \\
\hline State House Seats & - & - & - & - & $\begin{array}{l}-.132 \\
(.500)\end{array}$ & - \\
\hline Democratic Governor & - & - & - & - & $\begin{array}{l}-69.36 \\
(54.65)\end{array}$ & - \\
\hline $\mathrm{R}^{2}$ (Adj) & .35 & .40 & .27 & .31 & .29 & .41 \\
\hline
\end{tabular}


† Standard errors for each regression coefficient are reported within parentheses, where * indicates statistical significance at the 5 percent level or smaller. All regressions contain 50 state observations. The variable Senate Chairman $=1$ if a Senator from a state holds either the chairmanship or is the ranking minority member of a one of the following Senate fiscal committees: Appropriations, Banking and Urban Affairs, Budget, Commerce and Transportation, Environment and Public Works, and Finance. 
TABLE 3: DETERMINANTS OF 2009 ARRA FISCAL ASSISTANCE ${ }^{\dagger}$

\begin{tabular}{|c|c|c|c|c|c|c|c|}
\hline & $\begin{array}{c}\text { Total } \\
\text { Aid } \\
{[1]}\end{array}$ & $\begin{array}{c}\text { Total } \\
\text { Aid } \\
{[2]}\end{array}$ & $\begin{array}{c}\text { Stability } \\
\text { Aid } \\
{[3]}\end{array}$ & $\begin{array}{l}\text { Medicaid } \\
\text { Aid } \\
\text { [4] }\end{array}$ & $\begin{array}{c}\text { Highway } \\
\text { Aid } \\
{[5]}\end{array}$ & $\begin{array}{c}\text { Other } \\
\text { Aid } \\
\text { [6] }\end{array}$ & $\begin{array}{c}\text { Total } \\
\text { Aid } \\
{[7]}\end{array}$ \\
\hline $\begin{array}{c}\text { State Average } \\
\text { Per Capita } \\
\text { Gap or Aid }\end{array}$ & $\begin{array}{l}\$ 761 \\
(171)\end{array}$ & $\begin{array}{l}\$ 761 \\
(171)\end{array}$ & $\begin{array}{l}\$ 157 \\
(6)\end{array}$ & $\begin{array}{l}\$ 247 \\
(96)\end{array}$ & $\begin{array}{r}\$ 117 \\
(55)\end{array}$ & $\begin{array}{r}\$ 240 \\
(75)\end{array}$ & $\begin{array}{l}\$ 761 \\
(171)\end{array}$ \\
\hline Constant & $\begin{array}{c}695.9 \\
(34.09)^{* *}\end{array}$ & $\begin{array}{c}830.1 \\
(93.14)^{* *}\end{array}$ & $\begin{array}{l}161.3 \\
(4.02)^{* *}\end{array}$ & $\begin{array}{c}43.96 \\
(45.87)\end{array}$ & $\begin{array}{c}59.20 \\
(27.18)^{*}\end{array}$ & $\begin{array}{c}238.1 \\
(33.66)^{* *}\end{array}$ & $\begin{array}{c}415.2 \\
(88.75)^{* *}\end{array}$ \\
\hline $\begin{array}{c}\text { State UE } \\
\text { February, '09 }\end{array}$ & - & $\begin{array}{l}-19.00 \\
(12.30)\end{array}$ & $\begin{array}{l}-.719 \\
(.513)\end{array}$ & $\begin{array}{l}-3.94 \\
(5.39)\end{array}$ & $\begin{array}{c}.682 \\
(2.98)\end{array}$ & $\begin{array}{l}-1.79 \\
(4.31)\end{array}$ & $\begin{array}{l}-7.72 \\
(8.99)\end{array}$ \\
\hline $\begin{array}{c}\text { Budget Gap, } \\
2009\end{array}$ & $\begin{array}{l}.253 \\
(.098)^{* *}\end{array}$ & $\begin{array}{l}.321 \\
(.107)^{* *}\end{array}$ & $\begin{array}{l}.002 \\
(.004)\end{array}$ & $\begin{array}{l}.137 \\
(.044)^{* *}\end{array}$ & $\begin{array}{l}.052 \\
(.025)^{* *}\end{array}$ & $\begin{array}{l}.045 \\
(.035)\end{array}$ & $\begin{array}{l}.232 \\
(.075)^{* *}\end{array}$ \\
\hline $\begin{array}{r}\text { Medicaid } \\
\text { Exp, '05 } \\
\end{array}$ & - & - & - & $\begin{array}{l}.261 \\
(.036)^{* *}\end{array}$ & - & - & $\begin{array}{l}.392 \\
(.057)^{* *}\end{array}$ \\
\hline $\begin{array}{c}\text { Federal } \\
\text { Highways, '05 }\end{array}$ & - & - & - & - & $\begin{array}{l}3.43 \\
(.50)^{* *}\end{array}$ & - & $\begin{array}{l}3.95 \\
(1.49)^{* *}\end{array}$ \\
\hline $\begin{array}{c}\text { State } \\
\text { Population }\end{array}$ & - & - & $\begin{array}{l}.0001 \\
(.0001)\end{array}$ & $\begin{array}{c}.0030 \\
(.0015)^{* *}\end{array}$ & $\begin{array}{l}-.0024 \\
(.001)^{* *}\end{array}$ & $\begin{array}{l}-.0021 \\
(.0011)^{*}\end{array}$ & $\begin{array}{r}-.0004 \\
(.002)\end{array}$ \\
\hline $\begin{array}{l}\text { Senate } \\
\text { Chairman }\end{array}$ & - & - & $\begin{array}{c}2.81 \\
(1.99)\end{array}$ & $\begin{array}{l}-27.10 \\
(20.96)\end{array}$ & $\begin{array}{c}23.53 \\
(11.10)^{* *}\end{array}$ & $\begin{array}{c}32.27 \\
(16.69)^{* *}\end{array}$ & $\begin{array}{c}16.69 \\
(33.86)\end{array}$ \\
\hline $\begin{array}{c}\text { Close } \\
\text { Obama Vote }\end{array}$ & - & - & $\begin{array}{l}-.506 \\
(2.75)\end{array}$ & $\begin{array}{l}-11.60 \\
(28.61)\end{array}$ & $\begin{array}{c}13.96 \\
(15.22)\end{array}$ & $\begin{array}{l}-6.08 \\
(23.01)\end{array}$ & $\begin{array}{c}2.12 \\
(45.68)\end{array}$ \\
\hline $\mathrm{R}^{2}$ (Adj) & .10 & .12 & .06 & .59 & .67 & .10 & .55 \\
\hline
\end{tabular}

† Standard errors for each regression coefficient are reported within parentheses, where ** indicates statistical significance at the 5 percent level or smaller while * indicates statistical significance at the 10 percent level or smaller. All regressions contain 50 state observations. The variable Senate Chairman $=1$ if a Senator from a state holds either the chairmanship or is the ranking minority member of a one of the following Senate fiscal committees: Appropriations, Banking and Urban Affairs, Budget, Commerce and Transportation, Environment and Public Works, and Finance. The variable Close Obama Vote $=1$ if President Obama's vote share was within the threshold .50 to $.52,0$ otherwise. 


\section{REFERENCES}

Barro, Robert (1979), “On the Determination of Government Debt,” Journal of Political Economy, Vol. 87 (October), pp. 940-971.

Blanchard, Olivier and Larry Katz (1992), “Regional Evolutions,” Brookings Papers on Economic Activity, Vol. 1992 (Spring), pp. 1-75.

Blanchard, Olivier and Roberto Perotti (2002), “An Empirical Characterization of the Dynamic Effects of Changes in Government Spending and Taxes on Output," Quarterly Journal of Economics, Vol. 117 (November), pp. 1329-1368.

Bohn, Henning and Robert Inman (1996), "Balanced Budget Rules and Public Deficits: Evidence from U.S. States,” Carnegie-Rochester Conference Series on Public Policy, Vol. 45 (December), pp. 13-76.

Buettner, Thiess (2007), "Equalization Transfers and Dynamic Fiscal Adjustment: Results for German Municipalities and the U.S.-German Comparison,” Institute for Federalism and Intergovernmental Relations, WP 2007-07.

Gilligan, Thomas and John Matsusaka (1995), "Deviations from Constituent Interests: The Role of Legislative Structure and Political Parties in the States,” Economic Inquiry, Vol. 33 (July), pp. 383401.

Gordon, Roger (1983), “An Optimal Tax Approach to Fiscal Federalism,” Quarterly Journal of Economics, Vol. 95 (November), pp. 567-586.

Gramlich, Edward (1987), "Subnational Fiscal Policy,” Perspectives on Local Public Finance and Policy, Vol. 3, pp. 3-27.

Hou, Yilin and Daniel Smith (2006), “A Framework for Understanding State Balance Budget Requirement Systems: Reexamining Distinctive Features and an Operational Definition,” Public Budgeting and Finance, Vol. 26 (Fall), pp. 22-45.

Inman, Robert (1978), “The Fiscal Performance of Local Governments: An Interpretative Review,” in P. Mieszkowski and M. Straszheim (eds.), Current Issues in Urban Economics, Johns Hopkins Press: Baltimore, pp. 270-321.

Inman, Robert (1982), "Public Employee Pensions and the Local Labor Budget, Journal of Public Economics, Vol. 19 (October), pp. 49-72.

Inman, Robert. (1997), “Do Balanced Budget Rules Work? U.S. Experience and Possible Lessons for the EMU,” in H. Siebert (ed.), Quo Vadis Europe?, J.C.B. Mohr, Turingen, pp. 307-332. 
Inman, Robert (2002), “On Designing Intergovernmental Transfers with an Application in the New South Africa,” in A. Panagariya, P. Portney, and R. Schwab (eds.), Environmental and Public Economics: Essays in Honor of Wallace Oates, E. Elgar, Northampton, MA, pp. 222-252.

Inman Robert (2003), “Transfers and Bailouts: Enforcing Local Fiscal Discipline with Lessons from U.S. Federalism,” in J. Rodden, G. Eskeland, and J. Litvack (eds.), Enforcing a Hard Budget Constraint, MIT Press: Cambridge, MA., pp. 35-83.

Inman, Robert (2007), "Federalism's Values and the Value of Federalism," CESifo Economic Studies, Vol. 53 (Winter), pp. 522-560.

Inman, Robert (2008), “The Flypaper Effect,” NBER Working Paper No. 14579.

Inman, Robert and Andrew Haughwout (2001), "Fiscal Policies in Open Cities with Firms and Households,” Regional Science and Urban Economics, Vol. 31 (April), pp. 147-180.

Inman, Robert and Daniel Rubinfeld (1996), "Designing Tax Policy in Federalist Economies: An Overview,” Journal of Public Economics, vol. 60 (June), pp. 307-334.

Johnson, David, John Parker, and Nicholas Souleles (2006), “Household Expenditure and Income Tax Rebates in 2001,” American Economic Review, Vol. 96 (December), pp. 1589-1610.

Joyce, Philip (2001), “What's So Magical about Five Percent? A Nationwide Look at Factors That Influence the Optimal Size of State Rainy Day Funds?’ Public Budgeting and Finance, Vol. 21 (Summer), pp. 62-87.

Krelove, Russell (1992), “Competitive Tax Theory in Open Economies,” Journal of Public Economics, Vol. 48 (August), pp. 361-375.

Mieszkowski, Peter (1972), “The Property Tax: An Excise Tax or a Profits Tax?” Journal of Public Economics, Vol. 1 (April), pp. 73-96.

Rangel, Antonio (2005), "How to Protect Future Generations Using Tax-Base Restrictions," American Economic Review, Vol. 95 (March), pp. 314-346.

Rivlin, Alice (1992), Reviving the American Dream: The Economy, the States, and the Federal Government, Brookings Institution: Washington, D.C.

Rodden, Jonathan, Gunnar Eskeland, and Jennifer Litvack (2003), Enforcing a Hard Budget Constraint, MIT Press: Cambridge, MA.

Romer, Christine and David Romer (2010), “The Macroeconomic Effects of Tax Changes: Estimates Based on a New Measure of Fiscal Shocks,” American Economic Review, forthcoming. 
Sheffrin, Steven (2004), "State Budget Deficit Dynamics and the California Debacle," Journal of Economic Perspectives, Vol. 18 (Spring), pp. 205-226.

Shefter, Martin (1992), Political Crisis, Fiscal Crisis: The Collapse and Revival of New York City, Columbia University Press: New York.

Sobel, Russell and Randall Holcombe, "The Impact of Rainy Day Funds in Easing State Fiscal Crises During the 1990-1991 Recession,” Public Budgeting and Finance, Vol. 16 (Fall), pp. 28-48.

Wallis, John and Namshuk Kim (2005), "The Market for American State Government Bonds in Britain and the United States, 1830-1843,” Economic History Review, Vol. 58 (November), pp. 736764.

Wildasin, David (1989), "Interjurisdictional Capital Mobility: fiscal Externality and a Corrective Subsidy,” Journal of Urban Economics, Vol. 25 (March), pp. 193-212.

Wildasin, David (2000), "Labor Market Integration, Investment in Risky Human Capital, and Fiscal Competition,” American Economic Review, Vol. 90 (March), pp. 73-95. 